\title{
Ian Milligan \\ Rebel Youth: 1960s Labour Unrest, Young Workers, and New Leftists in English Canada
}

Vancouver: UBC Press, 2014. 252 pp.

\section{Roberta Lexier}

Mount Royal University

The 1960s are remembered as a period of confrontation, when young people challenged the status quo and effected substantial social change. Recently, a growing body of literature in Canada has attempted to add nuance to this myth of the Sixties. Ian Milligan's well-written and engaging book makes a significant contribution to this scholarship and to our conceptions of the period. The book challenges the typical focus on university students by adding the largely untold story of young workers, who vastly outnumbered their counterparts at institutions of higher learning.

Throughout his monograph, Milligan focuses on three related currents: the New Left, young workers, and youth culture. In doing so, he effectively demonstrates that workers and students were part of a "single youth phenomenon" (3) and that labour, generally overlooked in the scholarship, "significantly affected the direction of...political and cultural movements through the long sixties" (11). Based primarily on oral interviews, Milligan's research examines how identities were formed during the postwar period, whether there was a common youth culture in that era, how class consciousness influenced the upheavals of the Sixties, and how workers and students who sought social change interacted with one another. He begins in Chapter 1 with an overview of the postwar period and the important characteristics of a youth culture grounded in anti-authoritarianism, personal freedom, individual expression, and democracy that emerged at the time. The following chapter examines the rise of youth activism within Canadian labour unions in the Sixties and illustrates how young workers were inspired by the same concepts as their counterparts at universities. In Chapter 3, Milligan discusses the New Left and explains why many had written off workers as a potential force for social change; this limited the opportunities for alliances between the New Left and labour activists. The following two 
chapters explore interactions between New Leftists and unions in British Columbia, Saskatchewan, Ontario, and Nova Scotia and demonstrate the significance of the provincial context to the formation of relationships between on-campus activists and off-campus workers. Milligan's narrative concludes with an in-depth discussion of the Artistic Woodwork strike in Toronto, which saw New Leftists actively supporting workers who were once again seen as important agents for social change. His conclusion reiterates his argument that, while differences remained between workers and students and an opportunity was missed to join together into a powerful force, they nevertheless shared a common culture grounded in anti-authoritarianism and democracy. This, Milligan argues, can provide important lessons to future activists seeking to achieve social change.

Perhaps the greatest strength of Rebel Youth, apart from adding an untold story to the history of Canada's Sixties, is Milligan's argument that New Leftists and young workers shared aspects of a youth culture that emerged from the postwar context and influenced the activism of the 1960s. While he continually insists that young people had different experiences that shaped their identities, and that these were a grounded in class (as well as gender, race, etc.), he nevertheless provides ample evidence that students and workers shared an anti-authoritarian philosophy. "The shared desire for control and democracy could be seen among youth who went into the workplace. In this," he insists, "we can see evidence of a shared cross-class youth culture" (20). Milligan forces scholars to take seriously the activism of workers and to acknowledge that the conflicts of the time were grounded in a shared youth culture that emerged during the postwar period.

In order to strengthen this argument, Milligan needs to provide further context and explanation. For instance, while he provides some information about postwar Canada and identifies some of the key components of the shared youth culture, these discussions are relatively vague and could be explained. Moreover, the New Left is never adequately defined and some assumptions are made about the composition of this group, the actions taken by its members, and the ideas that informed their activities. Similarly, groups like the Waffle are mentioned repeatedly but never explained. Readers would require a solid background in the postwar period, the Sixties, and the various groups of activists to fully appreciate the significance of the argument presented.

In addition, Milligan's almost exclusive reliance upon oral history is somewhat problematic. Although he argues that few documents remain, while acknowledging as well that oral history has limits, he seems to uncritically accept the reminiscences of his interview subjects while overlooking some of the important documentary evidence that might challenge or even substantiate these claims. On a few occasions he mentions photographs as a source of information, but these are not included in the monograph; this would provide readers with another option to evaluate the efficacy of the argument presented.

That said, Milligan also effectively identifies the importance of the local context to the formation of alliances between New Leftists and labour activists. Although he claims that this is a national story, he does not always make clear the relationship 
between local case studies and this national narrative. Notwithstanding this shortcoming, his analysis of the unique political cultures in Saskatchewan and British Columbia in particular, and the ways that these contributed to a more effective offcampus activism for New Leftists, is a valuable contribution to the literature.

Overall, Rebel Youth makes an excellent contribution to the story of the 1960s in Canada. Milligan has ensured that young workers - the vast majority of youth — are included in the narrative of the period. He illustrates how workers, as well as students, contributed to the significant changes that occurred in Canada at the time. He also effectively demonstrates that the ideas at the core of New Left activism were not unique to the university context; the concepts of anti-authoritarianism, democracy, and self-expression were central to a broader youth culture and influenced rebellions that occurred in all areas of society, including the workforce. This monograph, while acknowledging the significantly different experiences of youth in Canada, successfully incorporates students and workers into a single, shared narrative of the Sixties and, as such, is a key resource for anyone interested in understanding the complexities of the era. 